\title{
Watershed master planning, City of Griffin, Georgia, USA
}

\author{
J. K. Kaplan \& B. J. Watson \\ Tetra Tech, Water Resources Group, Atlanta, Georgia, USA
}

\begin{abstract}
Tetra Tech has assisted the City of Griffin, Georgia (City) since 2003 with their stormwater and watershed planning needs. To date, work has included geomorphic assessments of streams, watershed modeling, Watershed Management Plans, a Stormwater Master Plan, and a Stormwater Capital Cost Recovery Plan. The effort has followed a holistic approach that includes the evaluation of problems and opportunities at the site and subwatershed scale, while considering cost-effectiveness and environmental sustainability at the watershed scale. Funding for these projects has come through the City's stormwater utility, which was the first one in the State of Georgia. Tetra Tech has developed Watershed Management Plans for each of the City's three major watersheds. Each plan includes three components: a Watershed Monitoring, Assessment, and a Protection Plan. The Watershed Assessments characterize the watersheds and identify problems and management needs in each subwatershed. The Watershed Protection Plans lay out a strategy for addressing the problems through a combination of programmatic measures, stormwater Best Management Practices (BMPs), and stream restoration projects. In order to provide a mechanism for the City to help fund the recommended BMPs, Tetra Tech developed a Stormwater Capital Cost Recovery Plan which establishes a watershed impact fee for new development and re-development. The planning documents that Tetra Tech developed for the City's Stormwater Division all work together to support a path forward that has specific goals, a well-defined implementation plan, and the financial mechanisms necessary for success. The process that Tetra Tech used to evaluate watershed needs and develop planning and guidance documents is innovative, practical, and applicable to other local and regional watershed planning efforts.

Keywords: stormwater, watershed, master planning, protection, monitoring, implementation, management, stream restoration, BMPs, modeling.
\end{abstract}




\section{Introduction}

The City of Griffin, Georgia (City) sits on the Eastern continental divide of the United States, in the headwaters of the Flint and Ocmulgee River basins. Watershed management actions in this city have an effect on water quality all the way to Altamaha Sound on the east coast of Georgia, and all the way to Apalachicola Bay in the panhandle of Florida. The City's Stormwater Division has, over the past 15 years, developed a sound Stormwater Program that ensures protection of local waterbodies. The program continues to develop and evolve to meet new regulations, new practices and standards in stormwater management, and the changing needs of the City. Tetra Tech, an environmental consulting firm, has worked with the City since 2003 to assess the local watersheds and develop comprehensive planning and guidance documents.

Starting in 1997, the City moved to the forefront of the stormwater scene in Georgia when it implemented the first stormwater utility in the state. Prior to the implementation of the stormwater utility, the City had no funding mechanism dedicated to stormwater management. The budget for stormwater services was limited to basic operation and maintenance activities and reactive measures to address emergency flooding and infrastructure repairs.

The City operates a municipal separate storm sewer system (MS4), which is a conveyance system for stormwater composed of storm drains, ditches, pipes, etc., which ultimately discharge into local waterbodies. To prevent harmful pollutants from being washed or dumped into an MS4, operators must obtain a National Pollutant Discharge Elimination System (NPDES) permit and develop a stormwater management program. The MS4 Program requires the implementation of minimum control measures for the reduction of pollutants entering receiving waters. In order to better meet the requirements of the City's MS4 NPDES permit, the Stormwater Division was created within the Department of Public Works, and a formal Stormwater Management Program was established. The stormwater utility was developed as a funding mechanism for the operation of the program and for projects dedicated to watershed improvement.

\section{Proactive stormwater planning}

Since its inception, the Stormwater Division has been proactive in stormwater planning and watershed management efforts. It has been successful at implementing a variety of programmatic and structural Best Management Practices (BMPs) to fulfil MS4 permit obligations. In addition, success has been realized in financial stability for the Division, improved planning and management, and in the development of education and community involvement programs. Funding provided by the stormwater utility allowed the Division to get organized. A small staff was hired to develop and administer programs, oversee monitoring, operations, and maintenance, and apply for additional funds such as Clean Water Act Section 319 grants and state-sponsored grants and loans. With resources devoted to the effort, the stormwater management program 
quickly blossomed into one of the City's most accomplished, well-functioning programs.

In the fifteen years that the City's Stormwater Division has been in existence, it has made commendable progress. Today, the Division operates on par with stormwater programs in much larger cities. The City has prepared manuals and guidance documents to assist planners and engineers, and establish city-wide standards, including a Stormwater Design Manual and Standard Operating Procedures for MS4 Operation and Maintenance. An inventory of all stormwater drainage structures and features within the City limits is maintained in a Geographic Information System (GIS) database, and stormwater operation and maintenance activities are logged using an electronic tracking system. Over 700 miles of roadway are cleaned each year through a street sweeping program, and road culvert pipes are inspected on a regular basis. The City has also taken many notable actions to prepare for large storm events and reduce flood risks, which has earned the City a CRS-5 rating through the Federal Emergency Management Agency's (FEMA's) Community Rating System (CRS). This designation gives citizens a 25\% reduction on flood insurance premiums.

Getting the community involved has been a great way to spread the word about the important programs the Stormwater Division has put in place, and it also helps citizens understand that their monthly utility fee is going to good use. Hundreds of pounds of garbage, tires, and recyclable materials are removed from waterways each year through community stream clean-up events. A curb-marker program gets kids involved with watershed protection by having them install small plaques on storm drains: "No Dumping - Drains to Stream". The City also promotes regional networking and education by hosting an annual Erosion Control \& Stormwater Workshop every October.

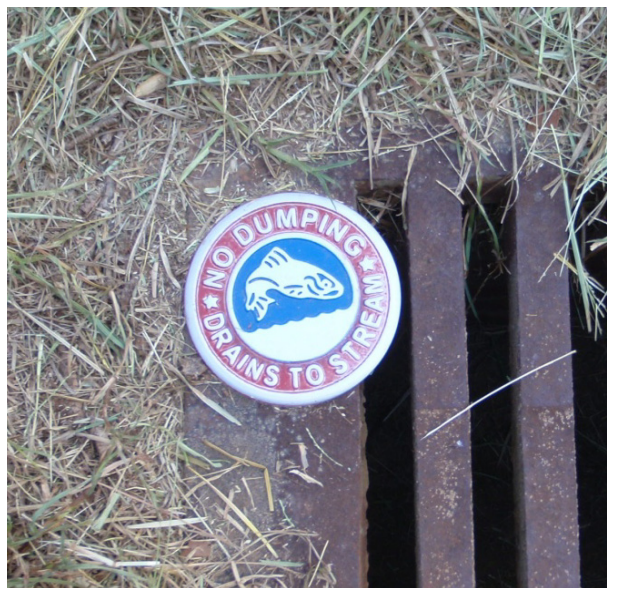

Figure 1: A storm drain marker installed by one of the community groups with whom the Stormwater Division has partnered. 


\section{Watershed-based stormwater management}

Griffin has adopted a watershed-based approach to stormwater management. The City, with the help of Tetra Tech, recently completed Watershed Protection Plans for each of the city's three major watersheds: Cabin Creek, Shoal Creek, and Potato Creek. The Plans address watershed problems and management needs identified through geomorphic assessments, water quality analysis, and hydrologic modelling.

The first step that must be taken to protect a watershed is to accurately identify the nature and location of problems in the watershed. In general, streams in Griffin are experiencing ecological degradation that is typical of urban watersheds. The streams have been affected directly through channelization, and indirectly through land development that has altered the volume, velocity, and quality of stormwater runoff. These alterations have also lead to increased stream bank erosion. Two of the City's streams are on the Clean Water Act's Section 303(d) list of impaired streams as not meeting their designated use of fishing. They are listed as Biota impacted, due to sedimentation.

Tetra Tech conducted Watershed Assessments [1, 2] to accurately characterize the City's watersheds and identify management needs. The City had several years' worth of water quality data, and Tetra Tech analyzed the data by creating time series graphs, calculating average parameter measurements for each monitoring station, and calculating pollutant loads. The assessments identified several locations that were exceeding water quality benchmarks, specifically for Total Suspended Solids (TSS), Total Nitrogen (TN) and Total Phosphorus (TP). Tetra Tech also conducted Geomorphic Assessments in each of the stream systems to identify areas of high bank erosion activity [3-5]. This data was evaluated in conjunction with land use data to identify management needs for subwatersheds within each watershed. Maps were created that identify the specific problems in each subwatershed, including hydrology, sediment, nutrients, biota, and fecal coliform bacteria.

Tetra Tech developed Watershed Protection Plans [6-8] based on findings from the Watershed Assessments. These plans lay a path forward to address the City's watershed management needs. It was determined that management measures in the City should focus on BMPs that will reduce flows and filter pollutants, and stream restoration measures that will stabilize banks and reduce instream sediment sources. In order to provide the Stormwater Division with a solid course of action, Tetra Tech identified and evaluated potential project sites based on GIS analysis, field assessments, and input from the City. Candidate project sites were scored and ranked based on criteria that were aligned with the City's objectives. As an example, Table 1 shows the scoring of BMP project sites in one of the City's 3 major basins, the Potato Creek watershed. 
Table 1: $\quad$ Scoring of candidate BMP projects.

\begin{tabular}{|c|c|c|c|c|c|c|c|c|c|c|c|c|}
\hline $\begin{array}{l}\text { BMP Ranking } \\
\text { Attribute }\end{array}$ & 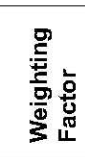 & $\frac{\frac{0}{m}}{\sum_{0}^{m}}$ & 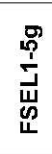 & 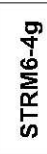 & $\begin{array}{l}\text { D } \\
0 \\
0 \\
0 \\
0\end{array}$ & 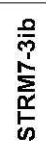 & 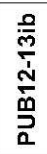 & 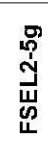 & 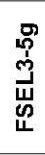 & 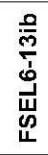 & $\frac{\stackrel{0}{m}}{\underset{j}{j}}$ & 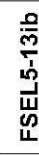 \\
\hline $\begin{array}{l}\text { Drainage area } \\
\text { treated }\end{array}$ & 1 & 5 & 5 & 10 & 5 & 5 & 0 & 0 & 5 & 2.5 & 5 & 5 \\
\hline Ownership & 1 & 0 & 10 & 0 & 10 & 0 & 10 & 10 & 0 & 10 & 10 & 10 \\
\hline Education potential & 0.5 & 0 & 5 & 0 & 0 & 0 & 5 & 0 & 0 & 5 & 0 & 0 \\
\hline Maintenance needs & 1 & 0 & 0 & 0 & 5 & 0 & 0 & 0 & 0 & 0 & 5 & 5 \\
\hline Storm flow control & 2 & 5 & 15 & 0 & 0 & 5 & 5 & 5 & 20 & 5 & 20 & 20 \\
\hline Pollutant reduction & 2 & 10 & 16 & 20 & 18 & 6 & 4 & 0 & 12 & 2 & 8 & 14 \\
\hline $\begin{array}{l}\text { LID, green, or } \\
\text { innovative BMP }\end{array}$ & 0.5 & 5 & 5 & 5 & 0 & 5 & 5 & 5 & 5 & 5 & 0 & 0 \\
\hline $\begin{array}{l}\text { Removal efficiency } \\
\text { cost }\end{array}$ & 2 & 14 & 18 & 20 & 12 & 14 & 6 & 4 & 10 & 0 & 4 & 10 \\
\hline Total Score & & 39 & 74 & 55 & 50 & 35 & 35 & 24 & 52 & 30 & 52 & 64 \\
\hline Rank & & 7 & 1 & 3 & 6 & 8 & 8 & 11 & 4 & 10 & 4 & 2 \\
\hline
\end{tabular}

After the initial scoring and ranking of the candidate projects was complete, BMP modelling was performed to estimate the potential pollutant removal efficiencies and cost effectiveness of the site-specific BMPs. The modelling tool that was used is BMPDSS Navigator, which Tetra Tech developed for the City. Optimization modelling was conducted in BMPDSS Navigator to develop an optimized suite of BMPs for each watershed based on nutrient reduction capabilities and costs.

Tetra Tech prepared project information sheets for each proposed BMP measure to provide the City with a quick-reference resource for comparing and selecting projects for implementation. An example project information sheet is shown in Figure 2.

The top ranking BMP in the Potato Creek watershed, FSEL1-5G shown in Table 1 and Figure 2 was the first project selected for implementation. Currently, Tetra Tech is in the process of designing this BMP which is a wetland-bottom detention basin at the upper end of an eroding drainage channel that runs through the City's cemetery. The feature will attenuate peak flows in the headwaters of the Potato Creek watershed, improve the hydrology and sediment loads for areas downstream, and add a diversity of native vegetation to an area that is currently dominated by manicured grass. As a result, this project will improve habitat for fish, birds, insects, and other urban wildlife. It will also provide an attractive place for visitors to the cemetery to sit and enjoy nature. 


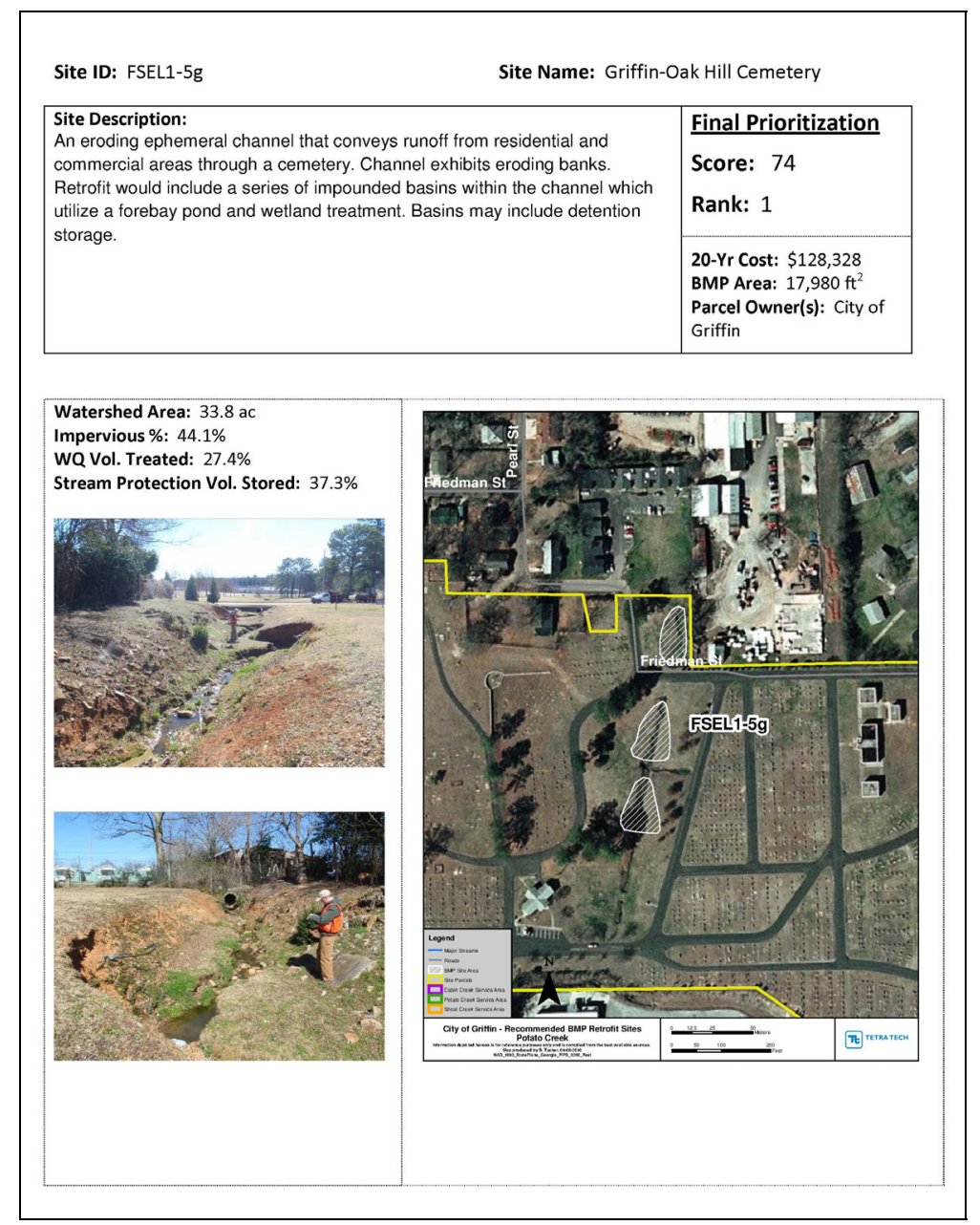

Figure 2: $\quad$ Project information sheet for a proposed BMP.

In order to help fund this project and other proposed watershed improvement projects, the City worked with Tetra Tech to develop a Stormwater Capital Cost Recovery Plan [9]. The Plan calls for a watershed impact or rehabilitation fee that will be charged to developers on a per-acre basis for land disturbance activities in the City. A cost per acre rate was established for each watershed based on the cost of the BMPs recommended for the watershed divided by the total acreage of the watershed within city limits. The impact fee will help offset costs associated with measures proposed in the Watershed Protection Plans. It will also encourage low-impact development through financial incentives. If successful, the Plan will provide an additional source of revenue for the Stormwater Division, and promote a development model that highlights water resources as an asset to the community. Based on projections of future growth 
and development, this fee will generate over \$2 million dollars (US) in revenue over the next twenty years for the City's Stormwater Division.

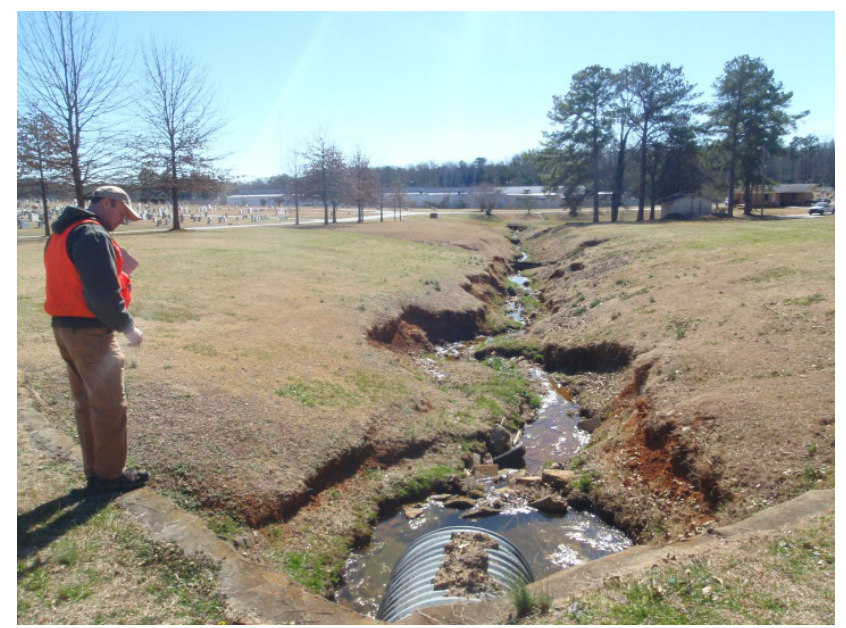

Figure 3: A Tetra Tech stormwater engineer inspects the site where a wetland-bottom detention basin will be constructed.

In addition to the individual Watershed Management Plans, Tetra Tech developed a Stormwater Master Plan for the City [10] in 2011. An initial Stormwater Master Plan was prepared for the City in 2003 [11], which presented the Stormwater Division's organizational structure and function as it related to the newly formed Stormwater Utility at that time. The updated 2011 Plan presents the current direction of the Stormwater Division in light of the programs that are currently in place, the City's MS4 NPDES permit commitments, and the Watershed Management Plans that have recently been completed for the Shoal Creek, Cabin Creek, and Potato Creek Watersheds. It details the current operational structure of the Stormwater Division, summarizes work and projects that have been done, and proposes a course of action for the Stormwater Division with respect to the Division's financial and programmatic goals. The document also references all of the other planning and guidance documents, City ordinances, and other resources used by the Stormwater Division. The Stormwater Master Plan is an all-encompassing planning document that provides a comprehensive view of Stormwater Division and a blueprint for future efforts.

\section{Conclusions}

The City of Griffin has one of the most successful stormwater programs in the State of Georgia. The City's program is successful because the Stormwater Division is proactively engaged in program development, and they take a strategic approach to watershed management. As a result, the City has saved a great deal of time, money, and labor. Investments in technology have allowed 
staff to work more efficiently and investments in studies have identified costeffective solutions, making the most of the Division's resources. The City's forward thinking and smart approach to decision-making will allow the Division to continue to protect its watersheds and meet the needs of its citizens.

\section{References}

[1] Tetra Tech. 2009. Cabin Creek Watershed Assessment. Tetra Tech, Inc. Atlanta, GA.

[2] Tetra Tech. 2009. Shoal Creek Watershed Assessment. Tetra Tech, Inc. Atlanta, GA.

[3] Tetra Tech, 2004. Stream Channel Stability Assessment of the Cabin Creek Watershed, Griffin, Georgia. Tetra Tech, Inc. Atlanta, GA.

[4] Tetra Tech, 2004. Stream Channel Stability Assessment of the Shoal Creek Watershed, Griffin, Georgia. Tetra Tech, Inc. Atlanta, GA.

[5] Tetra Tech, 2008. Stream Channel Erosion Activity Assessment of the Potato Creek Watershed, Griffin, Georgia. Tetra Tech, Inc. Atlanta, GA.

[6] Tetra Tech. 2012. Cabin Creek Watershed Protection Plan. Approved by GA EPD March 19, 2012. Tetra Tech, Inc. Atlanta, GA.

[7] Tetra Tech. 2012. Potato Creek Watershed Protection Plan Update. Approved by GA EPD April 13, 2012. Tetra Tech, Inc. Atlanta, GA.

[8] Tetra Tech. 2012. Shoal Creek Watershed Protection Plan. Approved by GA EPD March 19, 2012. Tetra Tech, Inc. Atlanta, GA.

[9] Tetra Tech. 2012. City of Griffin Stormwater Capital Cost Recovery Plan. Tetra Tech, Inc. Atlanta, GA.

[10] Tetra Tech. 2011. City of Griffin Stormwater Master Plan. Tetra Tech, Inc. Atlanta, GA.

[11] Integrated Science and Engineering. 2003. Stormwater Master Plan Program. 